\title{
PENGAPLIKASIAN PUPUK KOMPOS DAN PESTISIDA NABATI UNTUK PENINGKATAN PRODUKTIVITAS TANAMAN PERTANIAN MASYARAKAT
}

\author{
Husain Latuconsina1, Siti Zulaikha², Asmiyati Sahbudin ${ }^{3}$, Dzikriatu Nurlailah ${ }^{3}$, \\ Nadriani Bahrudin 4, M. Sahubaqul Iman Rohmada², Miftakhul Ikhsan5, Firli \\ Handika5, Firman Robbani ${ }^{5}$, Muh Dhiyaurroham ${ }^{4}$ \\ ${ }^{1}$ Fakultas Matematika dan Ilmu Pengetahuan Alam, Universitas Islam Malang \\ ${ }^{2}$ Fakultas Agama Islam, Universitas Islam Malang \\ ${ }^{3}$ Fakultas Keguruan dan Ilmu Pendidikan, Universitas Islam Malang \\ ${ }^{4}$ Fakultas Ekonomi dan Bisnis, Universitas Islam Malang \\ ${ }^{5}$ Fakultas Teknik, Universitas Islam Malang
}

Korespondensi email: husainlatuconsina@ymail.com

\begin{abstract}
ABSTRAK
Desa Mulyoasri Kecamatan Ampelegading, Kabupaten Malang berlokasi dibawah kaki gunung semeru, mayoritas masyarakat Desa berprofesi sebagai petani dan peternak. Persoalan yang dihadapi masyarakat adalah masih pengaplikasian kotoran kambing secara langsung tanpa diolah terlebih dahulu menjadi sebuah pupuk kompos dan masih menggunakan pestisida sintetis untuk meningkatkan produktivitas hasil pertanian mereka. Untuk mengatasinya, maka mahasiswa KKN-PPM Tematik berbasis Desa yang tergabung dalam kelompok 22 Universitas Islam Malang merancang dan mengimplementasikan program kerja yang didasarkan pada hasil survei dengan metode purposive sampling. Tema progam unggulan adalah "Pengapikasian Pupuk Kompos dan Pestisida Nabati untuk Peningkatan Produktivitas Tanaman Pertanian Masyarakat". Tujuan kegiatan pemerdayaan ini adalah untuk melatih masyarakat dalam mengintegrasikan kegiatan pertanian dan peternakan. Metode pemberdayaan yang dilaksanakn meliputi 1) penyuluhan, 2) pelatihan dan 3) pengaplikasi produk pupuk kompos kotoran kambing dan pestisida nabati dari ekstrak daun pepaya kepada masyarakat petani. Hasilnya masyarakat sangat antusias dengan kegiatan pemberdayaan ini dan merasakan manfaatnya serta mampu membuatknya secara mandiri. Pengaplikasian pupuk kompos dan pestisida nabati memperlihatkan hasil yang positif, di mana pertumbuhan tanaman sangat baik dan terhindar dari serangan hama. Outcome yang diharapkan dari kegiatan pemberdayaan ini adalah masyarakat petani lebih mandiri dalam upaya meningkatkan produktivitas tanaman perkebunan mereka melalui inovasi penggunaan pupuk kompos dan pestisida nabati yang lebih ramah lingkungan.
\end{abstract}

Kata Kunci: pupuk kompos; kotoran kambing; pestisida nabati.

\section{PENDAHULUAN}

Sebagai salah satu desa yang berlokasi di bawah kaki gunung semeru, mayoritas masyarakat Desa Mulyoasri, Kecamatan Ampelgading, Kabupaten Malang berprofesi sebagai petani perkebunan dan peternak. Untuk mengidentifikasi permasalahan yang ada di Desa Mulyoasri, maka mahasiswa peserta Kuliah Kerja Nyata - Pembelajaran Pengabdian Masyarakat Tematik (KKN-PPM Tematik) melakukan survei dengan mendatangi dan melakukan konstultasi publik dengan berbagai stakeholders (kepala desa, perangkat desa, tokoh masyarakat dan masyarakat petani). 
Berdasarkan hasil survei, ditemukann beberapa permasalahan yang dihadapi oleh masyarakat dusun Mulyoasri, Desa Mulyoasri adalah masyarakat petani/peternak masih mengaplikasikan kotoran kambing secara langsung tanpa diolah terlebih dahulu menjadi sebuah pupuk kompos dan masih mengunakan pesitisida kimiawi untuk mencegah serangan hama. Hal ini akibat kurangnya pemahaman proses pembuatan pupuk kompos dengan memanfaatkan limbah kotoran kambing serta belum mengenal pestisida nabati yang bahan dasarnya bersumber pada tanaman perkebunan.

Pupuk merupakan salah satu komponen penting dalam peningkatan produksi tanaman. Dewasa ini penggunaan pupuk mulai bergeser dari kimia menjadi organik khususnya pada tanaman hortikultura. Pergeseran ini salah satu penyebabnya adalah dengan penggunaan pupuk organik dalam jangka panjang dapat meningkatkan produktivitas lahan dan dapat mencegah degradasi lahan (Rastiyanto et al., 2013).

Menurut Hapsari (2013), limbah peternakan seperti feces, urine, dan sisa pakan dapat menyebabkan bau yang menyengat yang dapat merusak mutu lingkungan dan kesehatan masyarakat. Pengolahan kotoran ternak dapat dilakukan dengan menggunakan kotoran ternak sebagai pupuk kandang karena kandungan unsur haranya seperti nitrogen $(\mathrm{N})$, fosfor $(\mathrm{P})$, dan kalium $(\mathrm{K})$ yang dibutuhkan tanaman dan kesuburan tanah serta unsur hara mikro diantaranya kalsium, magnesium, belerang, natrium, besi, dan tembaga.

Sementnara itu penggunaan pestisida dengan bahan kimia aktif sangat toksik dan sulit terdegradasi, sehingga dapat menimbulkan berbagai dampak negatif pada lingkungan dan dapat menurunkan keragaman hayati dalam suatu koungitas biotik pada lingkungan.

Berdasarkan permasalahan yang ditemukan, maka mahasisa KKN-PPM Tematik Universitas Isalam Malang yang tergabung dalam Kelompok 22 berbasis Desa, merancang program pemberdayaan masyarakat dengan tema "Pemberdayaan Masyarakat Petani Melalui Pengalikasian Pupuk Kompos dan Pestisida Organik", yang pelaksanaannya melalui kegiatan penyuluhan, pelatihan dan pengaplikasian produk.

Adapun tujuan pelaksanaan KKN-PPM Tematik ini adalah untuk memperdayakan potensi masyarakat dengan memanfaatkan suberdaya alam yang ada agar dapat dimanafaatkan secara mandiri dan berkelanjutan.

\section{METODE}

\section{Lokasi dan Partisipan}

Pelaksanaan Pemberdayaan masyarakat melalui kegiatan Kuliah Kerja Nyata Pembelajaran Pemberdayaan Masyarakat Tematik dilaksanakan selama 1 bulan, dimulai sejak 1 Februari sampai dengan 1 Maret 2020, yang bertempat di Dusun Mulyoasti, Desa Mulyoasri, Kecmatan Amplegading, Kabupaten Malang - Jawa Timur (Gambar 1).

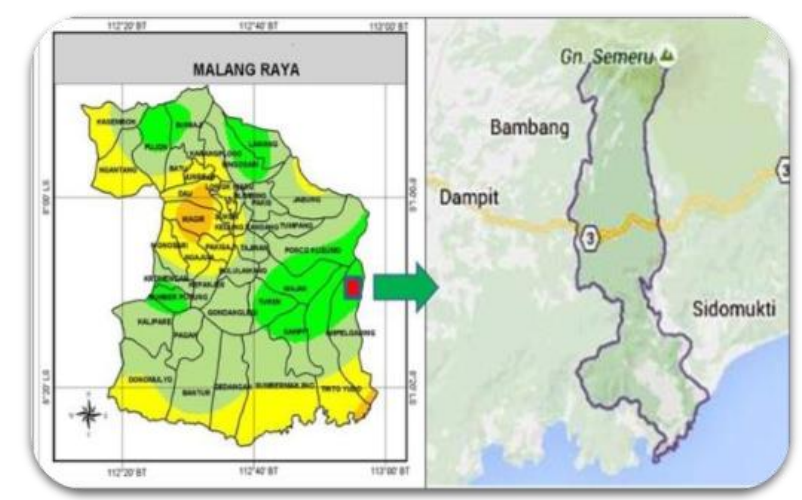

Gambar 1. Peta Lokasi Kegiatan KKN-PPM Tematik berbasis Desa, di Desa Mulyoasri, Kecamatan Amplegading, Kabupaten Malang - Jawa Timur 
Adapun masyarakat sasaran yang menjadi objek sekaligus subjek kegiatan pemberdayaan berbasis desan melalui pengablikasian pupuk kompos dan pestisida organik ini adalah masyarakat petani/peternak yang ada pada pedukuhan Mulyoasri, Desa Mulyoasri Kecamatan Ampegading, Kabupaten Malang - Jawa Timur.

\section{Bahan dan Alat}

Bahan yang digunakan dalam kegiatan pemberdayaan ini meliputi: kotoran kambing, air, molase (tetesan tebu), Effective Microorganism (EM4), daun pisang dan kelapa kering, sisa-sisa sayuran seperti kubis, kangkung dan daun gamal yang telah dipotong-potong. Semuanya ini digunakan untuk bahan dasar pembuatan pupuk kompos. Sedangkan detergen, air dan daun pepaya merupakan bahan dasar pembuatan pestisida organik. Alat yang digunakan adalah pisau/golok untuk memotong dedaunan, blender, saringan, wadah pastik dan lainya.

\section{Tahapan Kegiatan dan Metode Pemberdayaan}

Kegiatan pemeberdayaan masyarakat berbasis desa yang dilaksanakan oleh Mahasiswa peserta KKN-PPM Tematik Kelompok 22 dengan tema "Pemberdayaan Petani Melalui pengaplikasian Pupuk Kompos dan Pesisida Organik" dilasanakan dalam beberapa tahapan dan metode, yaitu: 1) Survei lokasi, 2) konsultasi publik dengan masyaraat (kepala desa dan perangkat desa, kepala dusun, dan masyarakat petani), 3) penyusunan program kerja pemberdayaan, 4) sosialisasi 5) penyuluhan, 6) pelatihan, 7) pengaplikasian, dan 8) Evaluasi.



Gambar 2. Silaturahmi sekaligus konsultasi public dengan perangat desa dan ketua kelompok tani di desa Mulyoasri

Pada tahapan identifikasi permasalahan di lapangan menggunakan metode Survai (Singarimbun dan Efendi, 1989) dan penentuan responden menggunakan metode purposif, yaitu dengan menentukan resppnen berdasarkan pertimbanganpertimabangan tetentu yang dinilai dapat memenuhi tujuan survei (Singarimbun dan Efendi, 1989; Nazir, 2011).

\section{HASIL DAN PEMBAHASAN}

\section{Program Unggulan KKN-PPM Tematik Kelompok 22 Berbasis Desa}

Program Pemberdayaan Petani Melalui Pengaplikasian Pupuk Kompos dan Pestisida Organik bertujuan untuk pembentukan kemandirian masyarakat Desa Mulyoasri dalam memanfaatkan limbah kotoran kambing dan pestisida organik 
berbahan dasar daun papaya yang mudah didapatkan. Program ini dilaksanakan dalam bentuk penyuluhan dan pelatihan.

Pelaksanaan program pemberdayaa berlangsung di Aula Gedung TK Dusun Mulyoasri dan dihadiri 22 orang, antara lain Kepala Dusun Mulyoasri, Narasumber (Hidayat Ali S.P), ketua Rt/Rw dari Dusun Mulyoasri, Kelompok Tani pria Dusun Mulyoasri, Kelompk Tani Wanita Desa Mulyasri, serta ibu-ibu warga dusun mulyoasri yang berprofesi sebagai Petani dan Peternak. Sosialisasi penyuluhan ini dilaksanakan pada pukul 14.00 WIB kemudian diadakan Pelatihan pembuatan Pupuk Kompos dan Pestisida Organik pada warga dusun Mulyoasri (Gambar 3).



Gambar 3. Kegiatan Penyuluhan dan dilanjutkan dengan praktek bersama dengan warga

Kegiatan pemberdayaan yang dilaksanakan oleh Mahasiswa KKN-PPM Tematik Kelompok 22 dari Universitas Islam Malang berbasis Desa dilaksanakan melalui beberapa metode yaitu: penyuluhan, pelatihan dan pengaplikasian produk. Makna penyuluhan dan pelatihan sendiri bukan hanya sekedar tindakan seperti pembekalan materi, tetapi dengan pembentukan karakter kepribadian yang mandiri. Pemberdayaan menurut Roesmidi dan Risyanti (2006) mengandung dua kecenderungan, yaitu: 1) menekankan kepada proses memberikan atau mengaihkan sebagian kekuasaan, kekuatan atau kemampuan kepada masyarakat agar individu menjadi lebih berda, dan 2) menekankan pada proses menstimulasi, mendorong atau memotivasi individu agar mempunyai kemampuan atau keberdayaan untuk menentukan apa yang menjadi pilihan hidupnya melalui proses dialog.

\section{Pembuatan Pupuk Kompos dari Kotoran Kambing}

Program unggulan Pemberdayaan Petani Melalui pengaplikasian Pupuk Kompos dari bahan dasar kotoran kambing dikarenakan hewan kambing merupakan hewan ternak yang banyak dikembangkan di desa Mulyoasri, Kecamatan Amplegading, namun pemilik kambing dan para petani belum memanfaatkan kotoran kambing secara maksimal. Mereka biasanya langsung menggunakan kotoran kambing tersebut ketanaman.

Pembuatan pupuk kompos berbahan dasar kotoran kambing dilakukan melalui beberapa tahapan-tahapan, mulai dari pengupulan kotoran kambing (Gambar 4), pengumpulan dedaunan dan proses pengerigan (Gambar 5), proses pemotongan dedunan kering dan sisa-sisa sayuran yang tidak termanfaatkan (Gambar 6), proses pencampuran Molase, EM4 dan penyiraman pada pebuatan pupuk kompos (Gambar 7). 


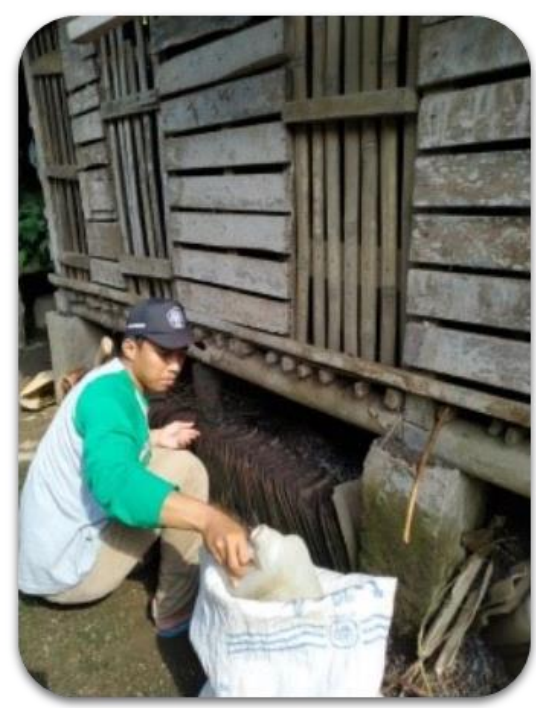

Gambar 4. Tahapan pengumpulan bahan dasar kotoran kambing yang berasal dari areal peternakan milik warga



Gambar 5. Pengumpulan dedaunan kering dan tahampan pengeringan (penjemuran)

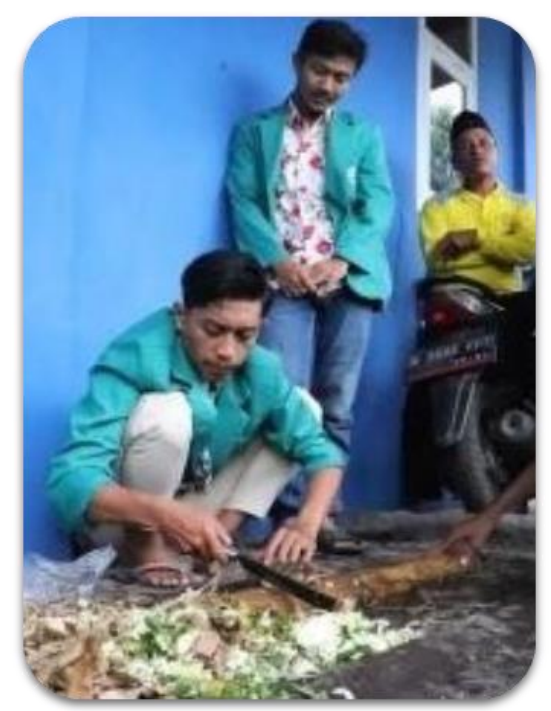

Gambar 6. Proses pemotongan dedunan kering dan sisa-sisa sayuran yang sudah tidak termanfaatkan 
Pengomposan membutuhkan rasio $\mathrm{C} / \mathrm{N}$ dan kadar hara untuk aktivitas mikroorganisme. Kandungan pada kotoran kambing yang digunakan sebagai bahan dasar pembuatan pupuk kompos menunjukkan bahwa bahan tersebut dapat digunakan sebagai bahan pembuatan kompos. Penambahan kotoran kambing merupakan faktor yang harus diperhatikan dalam pembuatan kompos. Selain itu untuk dapat memperccepat proses pengomposan maka ditambahkan Effective Microorganism (EM4) (Gambar 6).

Pengomposan menurut Dewi \& Tresnowati (2012) adalah proses penguraian bahan-bahan organik secara biologis oleh mikroba-mikroba yang memanfaatkan bahan organik sebagai sumber energy. Proses pengomposan yang terjadi secara alami menurut Arisha et al. (2003) berlangsung lambat, dan untuk mempercepat proses pengomposan telah dikembangkan teknologi-teknologi pengomposan, antara lain dengan menggunakan aktivator sehingga pengomposan berjalan dengan lebih cepat dan efisien. Bioaktivator yang digunakan adalah EM4, menurut Pangaribuan dan Pujisiswanto (2008), Mikroorganisme yang terdapat dalam EM4 antara lain Lactobacillus sp, Saccharomyces sp, Actinomycetes, dan cendawan pengurai selulosa.

Menurut Siboro et al. (2013), bahwa nilai rasio C/N pupuk kandang kambing umumnya diatas 30, oleh karena itu pupuk kandang kambing harus dikomposkan terlebih dahulu sebelum digunakan ke tanaman. Prinsip pengomposan adalah untuk menurunkan rasio $\mathrm{C} / \mathrm{N}$ bahan organik hingga sama dengan $\mathrm{C} / \mathrm{N}$ tanah $(<20)$.

Pengomposan membutuhkan rasio $\mathrm{C} / \mathrm{N}$ dan kadar hara untuk aktivitas mikroorganisme. Kandungan pada kotoran kambing menunjukkan bahwa bahan tersebut dapat digunakan sebagai bahan pembuatan kompos. Menurut Cahaya dan Nugroho (2009) bahwa pupuk yang berbahan dasar kotoran kambing mengandung nilai rasio $\mathrm{C} / \mathrm{N}$ sebesar 21,12\%. Menurut Hartatik $(2006)$, kadar hara kotoran kambing mengandung $\mathrm{N}$ sebesar 1,41\%, $\mathrm{P}$ sebesar 0,54\%, dan kandungan $\mathrm{K}$ sebesar 0,75\%. Dengan demikian penambahan kotoran kambing merupakan faktor yang harus diperhatikan dalam pembuatan kompos.

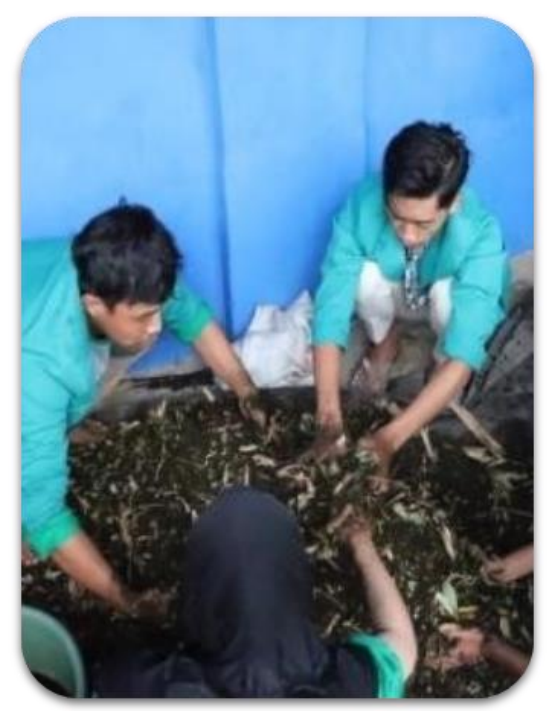

Gambar 7. proses pencampuran Molase, EM4 dan penyiraman pada pebuatan pupuk kompos

Menurut Darmasetiawan (2004), proses pengomposan juga membutuhkan bantuan mikroorganisme untuk mendekomposisi bahan dan mempercepat proses pengomposan. Mikroorganisme yang digunakan untuk mempercepat proses pengomposan adalah Effective Microorganism (EM4) sebagai salah satu faktor pengomposan yang berfungsi untuk 
mempercepat penguraian bahan organik, menghilangkan bau yang timbul selama proses penguraian, menekan pertumbuhan mikroorganisme patogen, dan meningkatkan aktivitas mikroorganisme yang menguntungkan.

Menurut Triviana et al (2017), kotoran kambing memiliki unsur hara yang diperlukan oleh tanaman tetapi perlu dilakukan pengomposan sebelum digunakan sebagai pupuk pada tanaman karena kotoran kambing memiliki rasio $\mathrm{C} / \mathrm{N}$ yang tinggi, yaitu $>30$. Pengomposan dilakukan dengan bioaktivator EM4 agar proses pengomposan berlangsung cepat. Pupuk Kotoran Kambing dapat menambah ketersediaan hara bagi tanaman dan meningkatkan kesuburan tanah. Penentuan komposisi bahan kompos dengan memvariasikan pupuk kotoran kambing (Sampah daun Pupuk kotoran kambing) (Muhammad et al., 2017).

Pembuatan pupuk kandang dari kotoran kambing dengan cara fermentasi menggunakan EM4 akan menyebabkan penurunan rasio $\mathrm{C} / \mathrm{N}$. Hal ini disebabkan dalam proses fermentasi telah terjadi reaksi C menjadi $\mathrm{CO} 2$ dan $\mathrm{CH} 4$ yang berupa gas. Selain itu, C-organik dalam bahan organik juga digunakan mikroorganisme sebagai sumber makanan sehingga jumlahnya berkurang. Sedangan, nilai $\mathrm{N}$ total dalam bahan organik mengalami peningkatan karena proses dekomposisi bahan kompos oleh mikroorganisme yang menghasilkan ammonia dan nitrogen, sehingga kadar $\mathrm{N}$ total kompos meningkat Bahan organik sudah menjadi kompos/pupuk dan dapat digunakan untuk tanaman apabila rasio $\mathrm{C} / \mathrm{N}<20$ (Yuniwati et al., 2012).

\section{Pembuatan Pestisida Nabati dari Daun Pepaya}

Pestisida adalah bahan atau zat kimia yang digunakan untuk membunuh hama bagi tanaman pertanian, baik yang dapat berupa serangga, tumbuhan, maupun hewan lainnya. Salah satu keluhan masyarakat petani adalah tanaman perkebunan mereka umumnya terserang hama (Gambar 8). Untuk memberantas hama penyerang tanaman perkebunan masyarakat petani di dusun Mulyoasri, Desa Mulyoasri kecamatan Amplegading masih menggunakan pestisida berbahan kimia.

Pestisida adalah substansi kimia dan bahan lain yang digunakan untuk mengendalikan berbagai hama. Menurut Cooper dan Dobson (2007), bahwa penggunaan pestisida yang bijaksana banyak menguntungkan manusia, seperti meningkatnya produksi tanaman karena menurunnya gangguan hama dan penyakit pada tanaman pertanian, sehingga dapat menjamin kesinambungan pasokan makanan hasil panen dan tersedianya bahan makanan, serta meningkatnya kesehatan, kualitas dan harapan hidup manusia. Meskipun demikian, menurut Supriadi (2013), bahwa penggunaan pestisida dengan bahan aktif yang sangat toksik dan sulit terdegradasi justru sangat berpotensi menimbulkan dampak negatif pada lingkungan, yang dapat berupa menurunnya populasi organisme yang menjad musuh alami hama, penuurunan keragaman hayati, dan pencemaran lingkungan.

Menurut Ariyanti et al. (2017), dari segi lingkungan pestisida kimia dapat menyebabkan pencemaran air berdampak luas, misalnya dapat meracuni sumber air minum, meracuni makanan hewan, ketidakseimbangan ekosistem sungai dan danau, pengrusakan hutan akibat hujan asam, dan sebagainya. Pestisida juga dapat mengubah perilaku dan morfologi pada hewan. 


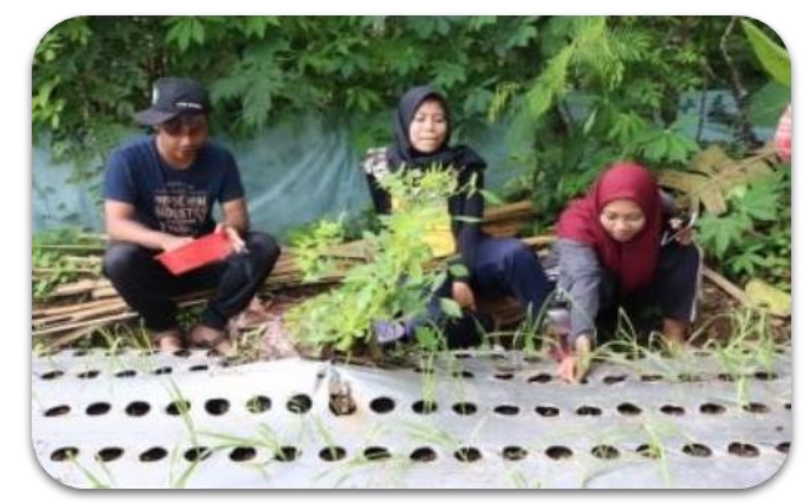

Gambar 8. Survei lokasi dan identifikasi permasalahan pada lahan pertanian milik masyarakat di dusun Mulyoasri, Desa Mulyoasri

Berdasarkan realitas ini, maka mahasiswa KKN-PPM Tematik berbasis Desa dari kelompok 22 Universitas Islam Malang, berinisitaif untuk mengembangkan pestisida nabati berbahan dasar Daun Pepaya yang mudah didapatkan di desa Mulyoasri. Maksud dari pembuatan pestisida nabati ini yang berasal dari bahan alam seperti tumbuhtumbuhan yang dapat menjadikan ramuan untuk mengendalikan hama dan penyakit tanaman.

Efektifitas pestisida nabati ini sanga terkait dengan kandungan senyawa kimianya yang bersifat racun (toxic), sehingga efektif dalam menolak (repellent) atau mencegah makan (deterrent) dari hama tumbuhan (Khater 2012). Sementara itu menurut Isman (2006), prospek penggunaan pestisida nabati sangat terbuka di negara-negara berkembang seiring dengan harga pestisida sintetis yang makin mahal.

Tujuan pembuatan pestisida yang berasal dari daun pepaya adalah membuat bahan-bahanya berasal dari alam sehingga pestisida ini lebih murah, ramah lingkungan dan lebih aman untuk kesehatan manusia (Gambar 9). Tanaman papaya sebagai bahan dasar pembuatan pestisida nabati mudah didapat karena masyarakat dusun Mulyoasri banyak yang membudidayakannya, sehingga bahan bakunya dapart tersedia secara berkelanjutan.

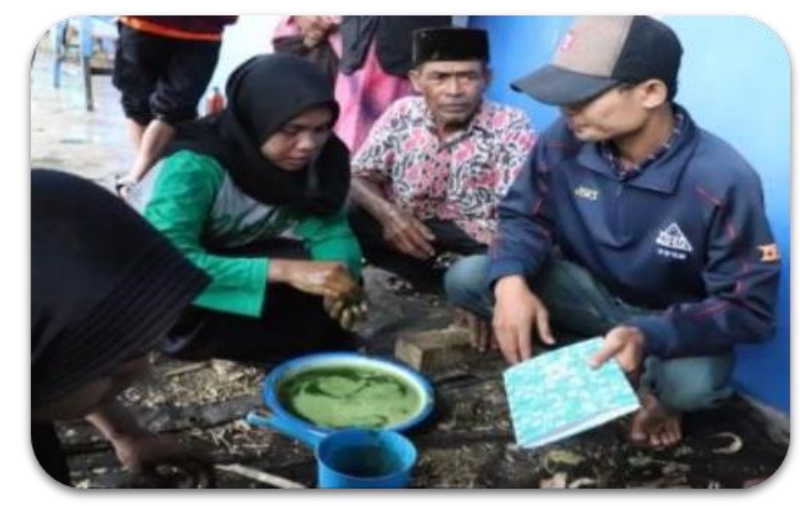

Gambar 9. Pembuatan pestisida nabati berbahan dasar daun peyaya (Carica papaya)

Kegiatan pembuatan pestisida nabati berbahan dasar daun papaya (Carica papaya) ini diharapkan dapat meningkatkan keterampilan masyarakat khususnya kelompo tani dalam menciptakan pestisida nabati yang efisien dan efektif serta ramah lingkungan. 


\section{Pengaplikasian Pupuk Kompos dan Pestisida Nabati pada Tanaman Pertanian}

Untuk semakin meyakinkan masyarakat, maka pemberdayaan masyarakat petani dilakukan melalui pengaplikasian pupuk kompos berbahan dasar kotoran kambing (Gambar 10) dan pestisida nabati berbahan dasar daun papaya (Carica papaya) pada tanaman pertanian milik masyarakat Dusun Mulyoasri (Gambar 11).

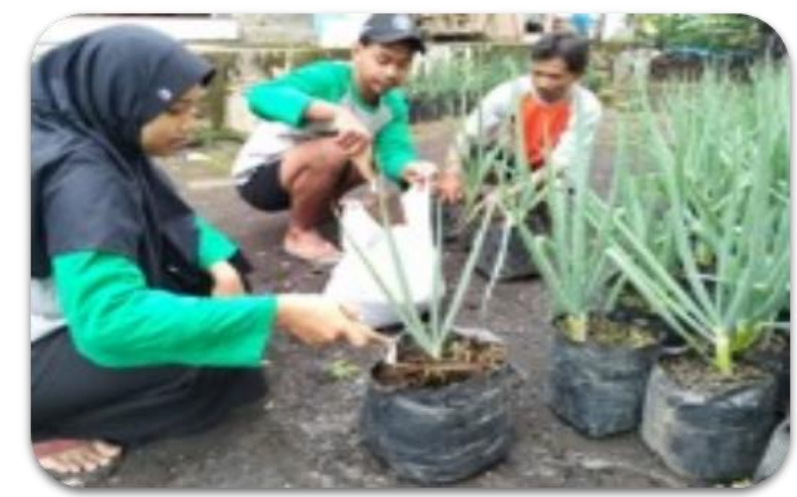

Gambar 10. Pengaplikasian pupuk kompos berbahan dasar kotoran kambing pada tanaman bawang milik masyarakat di pedukuhan Mulyoasri

Hasil monitoring dan evaluasi pada minggu ke-4 terlait performa tanaman bawang yang diberi pupuk kompos berbahan dasar kotoran kambing ternyata mepelihatkan hasil yang positif, dimana pertumuhannya cepat. Harapannya semoga metode pemupukan yang telah diterapkan pada kegiatan pemberdayaan oleh mahasiswa KKN-PPM Tematik berbasis desa oleh terus diaplikasikan secara berkelanjutan oleh masyarakat petani, agar dapat meningkatkan produktivitas hasil panen, sehingga diharapkan dapat meningkatkan pendapatan masyarakat petani di masa mendatang.

Seperti halnya dengan pengaplikasian pupuk kompos berbahan dasar kotoran kambing, ternyata hasil positif juga didapatkan pada pengaplikasian pestisida nabati berbahan dasar daun papaya (Carica papaya) yang diaplikasikan pada minggu ke-3. Dimana monitoring selama satu minggu memperlihatkan tanaman cabai yang telah disemprot dengan pestisida organik ekstrak daun papaya (Carica papaya) tidak menunukan adanya serangan hama pengganggu seperti yang selama ini dikeluhkan oleh para petani.

Hasil yang dipatkan ini diharapkan menjadi contoh bagi masyarakat kelompok tani untuk dapat mengoptimalkan potensi di desa untuk membuat pestisida nabati yang bahan dasarnyam udah didapatkan pada lingkungan desa.

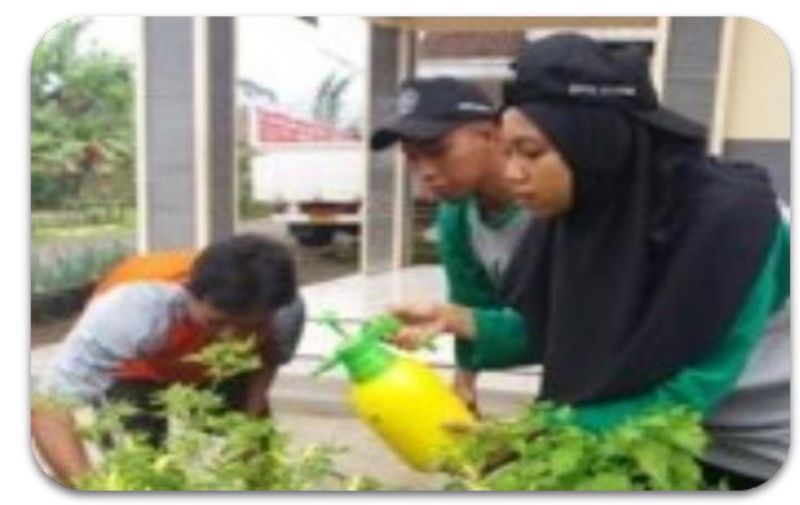

Gambar 11. Pengaplikasian pestisida organik berbahan dasar estrak daun papaya (Carica papaya) pada tanaman cabai milik masyarakat Pedukuhan Mulyoasri 
Menurut Anjum et al. (2013), daun papaya (Carica papaya) mengandung flavonoid (kaempferol, manghaslin, dan klitorin), saponin, alkaloid (karpain, pseudokarpain, dan dehidrokarpain I dan II), glikosida, fenol (asam ferulik, asam kafeik, dan asam klorogenik) dan enzim papain. Senyawa papain merupakan racun kontak yang masuk ke dalam tubuh serangga melalui lubang-lubang alami dari tubuh serangga.

\section{Tahapan-tahapan Kegiatan}

Kegiatan Pelaksanaan Kuliah Kerja Nyata - Pembelajaran dan Pengnabdian Mayarakat (KKN-PPM Teatik) berbasis desa dari kelompok 22 Mahasiswa Universitas Islam Malang, selama berada di lokasi KKN melakukan berbagai tahapan-tahapan kegiatan sebagaimana tertera pada Tabel 1.

Tabel 1. Tahapan Pelaksanaan KKN-PPM Tematik "Pengaplikasian Pupuk Kompos dan Pestisida Organik untuk peningkatan produktivitas hasil pertanian masyarakat"

\begin{tabular}{|c|c|c|c|}
\hline No. & $\begin{array}{l}\text { Tahapan- } \\
\text { tahapan }\end{array}$ & Uraian Kegiatan & Target Pencapaian \\
\hline 1. & Minggu Pertama & $\begin{array}{l}\text { Survei lokasi, konsultasi publik, } \\
\text { pembagian tugas dan merancang } \\
\text { program unggulan. }\end{array}$ & $\begin{array}{l}\text { Tersusunya Rencana Program kerja } \\
\text { Unggulan berbasis Desa }\end{array}$ \\
\hline 2. & Minggu Kedua & $\begin{array}{l}\text { Melakukan pemetaan program } \\
\text { pelatihan melalui Sosialisasi } \\
\text { Penyuluhan Pelatihan Pembutan } \\
\text { Pupuk Kompos }\end{array}$ & $\begin{array}{l}\text { Terealisasinya program kerja } \\
\text { unggulan dalam bentuk } \\
\text { penyuluhan dan pelatihan } \\
\text { pembuatan pupuk kompos dan } \\
\text { pestisida nabati }\end{array}$ \\
\hline 3. & Minggu Ketiga & $\begin{array}{l}\text { Melakukan Pengaplikasian Pupuk } \\
\text { Kompos dan Pestisida Organik pada } \\
\text { Tanaman bawang dan Cabai }\end{array}$ & $\begin{array}{l}\text { Terealisasinya kegiatan } \\
\text { pengaplikasian pupuk kompos dan } \\
\text { pestisida organik pada tanaman } \\
\text { bawang dan cabai milik masyarakat } \\
\text { petani }\end{array}$ \\
\hline 4. & Minggu Keempat & Evaluasi Pelaksanaan Program Kerja & $\begin{array}{l}\text { Terealisasinya seluruh tahapan } \\
\text { program kerja dengan baik }\end{array}$ \\
\hline
\end{tabular}

Dari empat tahapan kegiatan seperti pada Tabel 1, mulai dari tahap pertama yaitu survey dan konsultasi publik, dilanjutkan tahap ke-2 dengan pemantapan program dan implementasi program penyuluhan dan pelatihan, serta pengaplikasikan produk pada tahap ke-3, dan tahapn terakhir ke-4 berupa evaluasi pelaksanaan program kerja dilakukan berbasis kebutuhan masyarakat.

Tahapan evaluasi pelaksanaan program dilaksanakan untuk dapat mengetahui kekurangan dan kelemahan kegiatan yang telah dilakukan. Menurut Thomas et al. (2016), fokus untuk evaluasi menyangkut proses pelaksanaan kegiatan yang berkaitan dengan:

a. Tingkat efisiensi dan eketivitas pelaksanaan

b. Kemungkinan keberhasilan kegiatan sebagaimana yang direncanakan

c. Tindakan korektif yang diperlukan untuk memperbaiki demi efisiensi dan efektivitas pelaksanaan kegiatan

d. Tindakan-tindakan lain yang diperlukan sebagai pelengkap kegiatan yang telah direncanakan.

Dari hasil evluasi yang dilakukan, maka catatan penting yang perlu dilakukan untuk mencapai keberhasiln program kerja terkait pemberdayaan adalah:

a. Kegiatan Penyuluhan merupakan sesuatu yang mutlak untuk dilakukan yang didukung dengan pelatihan dan aplikasi sesuatu hal yang tekait dengan inovasi kepada masyrakat. 
b. Melakukan monitoring dan evaluasi secara simultan untuk mengetahui berbagai kendala yang dihadapi oleh masyarakat sebagai informasi dasar dalam upaya pemecahan masalah yang ditemukan.

\section{KESIMPULAN}

Kegiatan Kuliah Kerja Nyata - Pendidikan Pemberdayaan Masyarakat Tematik (KKNPPM Tematik) berbasis Desa yang dilaksanakan oleh Kelompok 22 Mahasiswa Universitas Islam Malang dengan Tema "Pengapliasian Pupuk Kompos dan Pestisida Nabati Untuk Peningkatkan Produktivitas Tanaman Pertanian Masyarakat" mendapatkan sambutan positif dari masyarakat pedukuhan Mulyoasri.

Dua program unggulan yang dilaksanakan adalah:1) Pembuatan dan pengaplikasian pupuk kompos berbahan dasar kotoran kambing, dan 2) Pembuatan dan pengaplikasian pestisida nabati berbahan dasar daun papaya (Carica papaya). Dua Program unggulan ini diakukan dengan didukung kegiatan penyuluhan untuk memberikan pengetahuan dasar bagi masyarakat khususnya kelompok tani pada dusun Mulyoasri tentang keunggulan penggunaan pupuk kompos berbahan dasar kotoran kambing dan pemanfaatan pestisida nabati berbahan dasar daun pepaya. Monitoring dan evaluasi pada minggu ke-4 mendapatkan hasil yang memuaskan baik pada penggunaan pupuk maupun pestisida nabati.

Harapannya semoga kegiatan pemberdayaan ini dapat membangun karakter kemadirian masyarakat petani di Desa Mulyoasri untuk secara mandiri berinovasi dalam upaya meningkatkan produktivitas hasil pertanian secara berkesinambungan.

\section{UCAPAN TERIMA KASIH}

Ucapan terima kasih disamapaikan kepada Kepala Desa Mulyoasri beserta Perangkat Desa dan kepala Dusun Mulyoasri yang telah menerima dan membantu mahasiswa peserta KKN-PPM Tematik selama 1 bulan penuh daam menjalankan program kerja. Ucapan terima kasih juga disampaikan kepada Panitia KKN-PPM Tematik dan Ketua LPPM Universitas Islam Malang yang telah memberikan kesempatan dan memudahkan terlaksananya kegiatan KKN-PPM Tematik.

\section{DAFTAR RUJUKAN}

Arisha, H.M.E., Gad, A.A., dan Younes, S.E. (2003). Response of some pepper cultivar to organic and mineral nitrogen fertilizer under sandy soil conditions. Zagazig J. Agric. Res. 30: 1875-99.

Anjum, Varisha, S. H. Ansari, Kamran J. Naquvi, Poonam Arora dan Adil Ahmad. (2013). Development of quality standards of Carica Papaya Linn. Leaves. Der Pharmacia Lettre, 5 (2),370-376.

Ariyanti, A., Yeni, E., Eyistia, S. (2017). Pembuatan pestisida nabati dengan cara ekstraksi daun peaya dan belimbing wuluh. Jom FTEKNI, 4(2), 1-9.

Cahaya, A.T dan Nugroho D.A. (2008). Pembuatan Kompos dengan Menggunakan Limbah Padat Organik (Sampah Sayuran dan Ampas Tebu). Semarang: Teknik Kimia Universitas Diponegoro.

Cooper, J. and H. Dobson. (2007). The benefits of pesticides to mankind and the environment. Crop Prot. 26: 1337-1348.

Darmasetiawan, M. (2004). Daur Ulang Sampah dan Pembuatan Kompos. Jakarta : Ekamitra Engineering.

Dewi, Y.S., Tresnowati. (2012). Pengolahan sampah skala rumah tangga menggunakan metode composting. Jurnal Ilmiah Fakultas Teknik LIMIT'S. 8(2): 35-48. 
Hapsari, A.Y. (2013). Kualitas dan kuantitas kandungan pupuk organik limbah serasah dengan inokulum kotoran sapi secara semianaerob .skripsi. Fakultas Keguruan dan Ilmu Pendidikan.Universitas Muhammadiyah Surakarta.

Hartatik, W. Dan Widowati, L.R. (2006). Pupuk Kandang, Pupuk Organik dan Pupuk Hayati. Bogor: Balai Besar Penelitian dan Pengembangan Sumber Daya Lahan Pertanian.

Isman, M.B. (2006). Botanical insecticides, deterrents, and repellents in modern agriculture and an increasingly regulated world. Annu. Rev. Entomol, 51, 45-66.

Khater, H.F. (2012). Prospects of botanical biopesticides in insect pest management. Pharmacologia, 3(12), 641-656.

Muhammad, T.A., Zaman, B., Purwanto. (2017). Pengaruh Penambahan pupuk kotoran kambing terhadap hasil pengomposan daun kering di TPST UNDIP. Jurnal Teknik Lingkungan, 6(3), 1 - 12.

Nazir, M. (2011). Metode Penelitian. Bogor: Ghalia Indonesia.

Pangaribuan, D., Pujisiswanto, H. (2008). Pemanfaatan kompos jerami untuk meningkatkan produksi dan kualitas buah tomat. Prosiding Seminar Nasional Sains dan Teknologi II 2008, Universitas Lampung, 17-18 November 2008. p. 1-10.

Rastiyanto E.A., Sutirman., Pullaila. A. (2013). Pengaruh pemberian pupuk organic terhadap pertumbuhan dan hasil tanaman kailan (Brassica oleraceae. L). Buletin IKATAN, 3(2), $36-40$.

Roesmidi, H., dan Risyanti, R. (2008). Pemberdayaan Masyarakat. Penerbit Alqaprint Jatinangor.

Siboro, E.S., Surya, E., Herlina, N. (2013). Pembuatan pupuk cair dan biogas dari campuran limbah sayuran. Jurnal Teknik Kimia, 2(3), 40-43.

Singarimbun, M dan Efendi, S. (1989). Metode Penelitian Survai. LP3ES. Jakarta.

Supriadi. (2013). Optimasi pemanfaatan beragam jenis pestisida untuk mengendalikan hama dan penyakit tanaman. Jurnak Litbang Pertanian, 32 (1), 1-9.

Trivana, L., Pradhana, A.Y., Manambangtua, A.P. (2017). Optimalisasi Waktu Pengomposan Pupuk Kandang dari Kotoran Kambing dan Debu Sabut Kelapa dengan Bioaktivator EM4. Jurnal Sains dan Teknologi Lingkungan, 9(1), 16 - 24.

Thomas, S., Suharyanto, W.D., Suwandi, A., \& Purwanto. (2016). Program dan Evaluasi Penyuluhan Pertanian. Penerbit Universitas Terbuka.

Yuniwati, M., Iskarima, F., Padulemba, A. (2012). Optimasi kondisi proses pembuatan kompos dari sampah organik dengan cara fermentasi menggunakan EM4. Jurnal Teknologi. 5(2), 172-181. 